\title{
Rancang Bangun Knowledge Management System Politeknik Statistika STIS
}

\author{
Ibnu Santoso ${ }^{* *}$, Sanjaya Abdillah Karim ${ }^{2}$, \\ ${ }^{1,2}$ Program Studi Komputasi Statistik, Politeknik Statistika STIS, Jakarta, Indonesia \\ ${ }^{1,2} \mathrm{Jln}$. Otto Iskandardinata No 64C, Jakarta Timur, 13330, Indonesia \\ email: ${ }^{1}$ ibnu@stis.ac.id, ${ }^{2}$ s.karim@bps.go.id
}

Copyright @2019, Politeknik Harapan Bersama, Tegal

\begin{abstract}
STIS Polytechnic of Statistics (PS-STIS) is an institutional unit with high work complexity and density. In carrying out its personnel activities, there is no support system that can be used by employees to store and process knowledge related to their work. This may indirectly lead to ineffective and inefficient work in term of costs, time, and other resources. Jobrelated knowledge is stored in accordance with the decisions of each employee. When needed, knowledge acquisition becomes slow and knowledge is also prone to be scattered or even lost. In this study, we will discuss about design and development of knowledge management system within the scope of PS-STIS. The focus of this research is related to the integration of the system functions to be able to perform knowledge storage, collaboration, and retrieval. The web-based system built applies the basic principles of Knowledge Management System (KMS). it has pages and permissions in accordance with the interests and responsibilities of users. In this research, we used SDLC development method to build the system and evaluated it using blackbox testing method and Survey Usability Scale (SUS). Result of blackbox testing showed that all function performed like expected and SUS score of 74 showed that system built was acceptable to users.
\end{abstract}

Abstrak - Politeknik Statistika STIS (PS-STIS) adalah unit institusi yang memiliki kompleksitas dan tingkat kepadatan pekerjaan yang cukup tinggi. Dalam menjalankan kegiatannya, saat ini belum terdapat sistem penunjang yang bisa digunakan oleh pegawai untuk menyimpan dan mengelola pengetahuan terkait pekerjaannya. Hal ini dapat menyebabkan pelaksanaan pekerjaan yang kurang efektif dan efisien, baik pada segi biaya, waktu, dan sumber daya institusi lainnya. Selama ini, pengetahuan terkait pekerjaan disimpan sesuai dengan keputusan masing-masing pegawai yang bersangkutan, sehingga tak jarang saat dibutuhkan, pengambilan pengetahuan menjadi lambat, pengetahuan juga rawan tercecer atau bahkan hilang. Penelitian ini membahas tentang perancangan dan pembangunan sistem manajemen pengetahuan pekerjaan dalam lingkup PS-STIS. Fokus pada penelitian ini adalah terkait pengintegrasian fungsi sistem untuk bisa melakukan penyimpanan, kolaborasi, dan pengambilan pengetahuan sekaligus sehingga terbentuk sentralisasi sistem manajemen pengetahuan pegawai. Sistem yang dibangun menerapkan prinsip dasar Knowledge Management System (KMS) berbasis web dan memiliki halaman dan permission bertingkat sesuai dengan kepentingan dan tanggungjawab pengguna. Penelitian dilakukan menggunakan metode System Development Life Cycle (SDLC), dan evaluasi sistem menggunakan metode blackbox testing dan Survey Usability Scale (SUS). Dari hasil blacbox

\footnotetext{
*) penulis korespondensi: Ibnu Santoso
}

Email: ibnu@stis.ac.id testing didapatkan hasil bahwa fungsi telah berjalan sesuai harapan dan dari hasil SUS didapatkan skor rata-rata sebesar 74 yang berarti sistem yang telah dibangun dapat diterima (acceptable) oleh pengguna.

Kata Kunci - KMS, penyimpanan, kolaborasi, pengambilan, pegawai.

\section{PENDAHULUAN}

Pada era digital saat ini, data merupakan salah satu aset paling berharga. Data menjadi hal pertama yang dibutuhkan sebelum melakukan berbagai aktivitas dan pekerjaan. Pekerjaan tersebut dapat efektif dan efisien diselesaikan apabila terdapat data dasar sebagai pendukung. Salah satu sifat data adalah mampu menggambarkan suatu hal secara spesifik, dimana data yang sejenis dapat membentuk suatu kumpulan data. Kumpulan data tersebut, apabila diolah lebih lanjut, seperti dengan mengkategorikan atau melakukan penghitungan terhadapnya, maka akan dihasilkan bentuk baru yang disebut informasi. Menurut [1], "Informasi adalah hasil dari pengolahan data dalam suatu bentuk yang lebih berguna dan lebih berarti bagi penerimanya yang menggambarkan suatu kejadian - kejadian (event) yang nyata (fact) yang digunakan untuk pengambilan keputusan". Menurut [2] Knowledge Management adalah program manajemen untuk mengelola dan menyatukan sekumpulan aktivitas akuisisi, penciptaan, dan pembagian pengetahuan.

PS-STIS, sebagai institusi sekaligus organisasi besar, tentu memiliki berbagai aktivitas pekerjaan yang kompleks didalamnya. Dalam hal ini, berbagai pekerjaan dan aktivitas yang terdapat dalam pelaksanaan PS-STIS harus diselesaikan dan dilaporkan secara rutin, sebagai salah satu bentuk kompetensi dalam menunjang dan menjalankan fungsinya sebagai instansi pendidikan di bawah Badan Pusat Statistik (BPS). Di dalam instansi PS-STIS, terdapat beberapa unit kerja yang menjalankan aktivitas pekerjaan, yang terdiri dari : unsur pimpinan, berupa direktur, wakil direktur, unsur pelaksana administrasi, (terdiri dari Bagian Administrasi Akademik Kemahasiswaan dan Bagian Administrasi Umum) unsur Pendidikan, (terdiri dari program studi statistika dan komputasi statistik), unsur unit penelitian dan pengabdian masyarakat, unsur unit perpustakaan, unsur penjamin mutu pendidikan, serta unsur unit informasi dan teknologi. Masing masing unit kerja memiliki kompleksitas dan keunikan pekerjaan masing-masing. 
Dalam pelaksanaan tugas, tidak jarang terdapat berbagai permasalahan dan kendala yang menghambat pekerjaan masing-masing unit kerja di PS-STIS. Hal ini, tentunya membuat pegawai ataupun stakeholder pada unit kerja yang bersangkutan harus bekerja ekstra untuk menyelesaikan masalah yang muncul. Selain itu, perputaran atau rotasi pegawai di PS-STIS tergolong cepat. Pergantian posisi dan jabatan yang cepat ini mengakibatkan transfer dan dokumentasi pengetahuan dari pegawai lama kepada pegawai baru dinilai belum berjalan optimal.

Berdasarkan dokumentasi permasalahan yang ada, penyebab utama yang mendasari tidak lekas terselesaikannya permasalahan diatas adalah belum terdapat sistem terintegrasi yang menjalankan fungsi dokumentasi, sharing dan retrieve file maupun pengetahuan di PS-STIS. Sistem informasi dokumentasi sharing dan retrieve tersebut penting untuk dibangun dan dijalankan di PS-STIS, sebab keberadaannya dapat menjamin ketersediaan file dan informasi dimanapun dan kapanpun dibutuhkan. Ketersediaan informasi dasar sebagai pendukung aktivitas pekerjaan dan penyelesaian masalah menjadi hal essensial yang diperlukan oleh institusi besar yang memiliki aliran data kompleks seperti PS-STIS.

Untuk menjawab persoalan terkait kebutuhan sistem informasi di PS-STIS, maka dalam penelitian ini dirancang sebuah knowledge management system yang mampu mengumpulkan, menyimpan, mendokumentasikan, dan mendistribusikan pengetahuan yang dibutuhkan sebagai pendukung stakeholder dalam menyelesaikan pekerjaan.

Dalam penelitian ini, peneliti berfokus pada perancangan sistem dengan spesifikasi secara umum, sehingga dapat diterapkan pada berbagai macam unit dan pengguna yang ada di PS-STIS. Kebutuhan dasar unit kerja di PS-STIS untuk menyelesaikan pekerjaan terkait manajemen knowledge dirangkum dan disediakan dalam sistem. Di dalam perancangan, sistem yang dibuat akan dibatasi pada beberapa cakupan. Cakupan yang akan dibahas pada penelitian ini terbatas pada pembuatan sistem web dan database yang mendukung sarana pertukaran, penyimpanan, pendokumentasian, dan pengambilan pengetahuan. Sementara cakupan organisasi hanya dibatasi pada unit kerja yang ada di PS-STIS. Spesifikasi sistem pun dibuat terbatas pada kebutuhan dasar masing-masing unit kerja. Untuk fitur spesialisasi suatu unit kerja dapat ditambahkan melalui evaluasi dan pengembangan sistem lebih lanjut.

\section{PENELITIAN YANG TERKAIT}

Knowledge atau pengetahuan, menurut [3] adalah seluruh kesadaran dan keterampilan yang digunakan oleh seseorang untuk memecahkan masalah. Pengetahuan tersebut mencakup teori maupun praktis, aturan sehari-hari atau petunjuk untuk melakukan tindakan. Dalam perkembangannya, pengetahuan seseorang dipengaruhi oleh beberapa faktor, yaitu pendidikan yang ditempuh, media yang digunakan dan informasi yang diperoleh.

Apabila dilihat dari perihal eksplisitasnya, pengetahuan dapat dibagi menjadi dua jenis utama, yaitu pengetahuan tacit dan eksplisit [4]. tacit knowledge adalah pengetahuan yang sulit atau tidak dapat diartikulasikan namun dapat ditransfer atau dikomunikasikan. Tipe knowledge ini terletak didalam pikiran atau melekat pada diri seseorang. Berbeda halnya dengan tacit, explicit knowledge adalah pengetahuan yang sudah direkam dan didokumentasikan sehingga lebih mudah untuk didistribusikan dan dikelola. Contoh dari pengetahuan ini adalah buku petunjuk pengoperasian sebuah mesin atau penjelasan sebelum melakukan suatu aktivitas tertentu.

Menurut [5], Knowledge Management System merupakan sistem informasi berbasis pengetahuan yang mendukung penciptaan, pengaturan, dan penyebaran pengetahuan bisnis dari dalam perusahaan kepada karyawan dan manajer.

Dalam kaitan dengan penelitian ini, terdapat beberapa penelitian terdahulu yang terkait dan digunakan sebagai referensi. Pada tahun 2017, terdapat penelitian pada jenjang Diploma IV di PS-STIS dengan judul Pembangunan Knowledge Management System Kendala dan Solusi Kegiatan Pencacahan Badan Pusat Statistik [6]. Penelitian ini lebih merujuk kepada pemanfaatan manajemen pengetahuan pada penyelesaian permasalahan lapangan saat pelaksanaan survey SUSENAS

Selain penelitian diatas, juga terdapat penelitian dengan judul Penerapan Knowledge Management System (KMS) Berbasis Web Studi Kasus Bagian Teknisi dan Jaringan Fakultas Ilmu Komputer Universitas Sriwijaya [7]. Pada penelitian ini, dijelaskan bagaimana cara menangkap pengetahuan yang dimiliki oleh pegawai pada Fakultas Ilmu Komputer Universitas Sriwijaya. Fitur yang dibuat memfasilitasi penangkapan knowledge dalam bentuk explicit dan tacit.

Penelitian lainnya [8] menjelaskan prototipe personal knowledge management pada pendidikan tinggi yang berfokus kepada mahasiswa yang akan mengambil kuliah pada program sarjana hingga akhir kuliah.

\section{A. Metode Pengembangan Sistem}

\section{METODE PENELITIAN}

Di dalam pengembangan system ini kami menggunakan model System Development Life Cycle (SDLC) [9]. Berikut ini dilampirkan tujuh kegiatan utama yang dilakukan:

1) Tahap perencanaan, Pada tahap pertama ini peneliti melakukan perencanaan awal dalam pengembangan sistem, seperti penentuan ruang lingkup dan tujuan pembuatan sistem, pencarian fakta dari subject matter, hingga mengatur jadwal pembuatan sistem dari awal hingga sistem selesai.

2) Tahap analisis, Setelah mengumpulkan data, tahapan selanjutnya adalah melakukan analisis sistem berjalan. Tujuan dari analisis ini adalah untuk mengumpulkan permasalahan permasalahan yang terdapat pada sistem yang diterapkan saat ini. Berbagai macam kelemahan dan kelebihan sistem yang ada didokumentasikan secara rinci.

3) Tahap perancangan, Perancangan pada tahap ini dapat berbentuk pembuatan bisnis proses baru yang diajukan, perancangan antarmuka sistem knowledge management usulan dari peneliti, hingga perancangan database sebagai fungsi penyimpanan informasi dan pengetahuan yang penting pada berbagai unit kerja di PS-STIS.

4) Tahap pengembangan, Pada tahap ini, rancangan dasar dari sistem sudah siap, meliputi rancangan basis data, rancangan bisnis proses, rancangan aktivitas didalam sistem, hingga rancangan antarmuka sistem yang mendukung kebutuhan dari subject matter. Selain itu, pada proses pengembangan aplikasi peneliti memastikan agar semua fungsi pada sistem berjalan sesuai dengan rancangan dan studi literatur yang dirujuk. 
5) Tahap Ujicoba, Tujuan dari tahap uji coba adalah memastikan bahwa sistem baru sudah sesuai dan dapat memenuhi kebutuhan subject matter. Metode pengujian dan evaluasi sistem yang dilakukan oleh peneliti adalah blackbox test dan system usability scale (SUS).

6) Tahap implementasi, Tahap implementasi berupa tahapan penyerahan sistem yang telah selesai dikembangkan kepada pengguna sebenarnya agar dapat segera diterapkan. Pada tahapan ini sistem harus sudah clear dari bugs dan error, serta seluruh fungsinya sudah dapat digunakan dengan baik oleh pengguna, sehingga sistem dapat menjawab tujuan awal, yaitu menyelesaikan masalah sistem berjalan yang ada.

7) Tahap pengoperasian dan pemeliharaan, Pada tahap ini, sudah dilakukan pengoperasian oleh pengguna sistem, serta dilakukan pemeliharaan selama sistem berjalan. Bentuk dari pemeliharaan sistem dapat berupa penambahan modul, package maupun fungsi baru untuk menambah fitur dari aplikasi ini. Selain itu, juga dilakukan evaluasi dan perbaikan ulang apabila muncul eror ditengah pengoperasian sistem.

\section{B. Metode Pengumpulan Data}

Dalam membangun sistem, peneliti menggunakan beberapa metode yang dibawah ini dalam mengumpulkan data:

1) Wawancara, Sebelum dilakukan pembangunan sistem, peneliti melakukan metode ini untuk menggali informasi lebih jauh. Wawancara yang dilakukan adalah dengan mengajukan pertanyaan-pertanyaan secara rinci terkait tujuan, manfaat, masalah yang ada, dan kebutuhan akan sistem yang diharapkan. Pada tahap awal penelitian, metode ini sangatlah efektif guna mengetahui gambaran umum tentang sistem berjalan yang ada. Pada tahap selanjutnya, konsultasi dan diskusi secara lebih dalam mengenai analisis dan rekomendasi sistem yang akan dibangun.

2) Observasi, Selain wawancara, metode pengumpulan data lain yang digunakan adalah observasi. Selain mendapatkan data dan informasi melalui wawancara, peneliti melakukan pengamatan langsung terhadap sistem berjalan yang ada pada salah satu unit di PS-STIS. Dengan dilakukan pengamatan tersebut, dapat langsung direkam aktivitas apa saja yang masih dilakukan secara manual serta kendalanya, sehingga dapat tergambar sistem yang cocok sebagai solusi permasalahan tersebut.

3) Studi Pustaka, Metode studi pustaka adalah salah satu media pengumpulan data paling akurat. Peneliti mengumpulkan data penunjang yang terkait dengan topik penelitian. Berbagai data dikumpulkan dari beberapa sumber, seperti buku, jurnal, artikel, penelitian lain yang terkait, dan sumber informasi lain yang terkait. Selain itu, kegunaan dari studi pustaka adalah dapat digunakan sebagai dasar serta bahan rujukan guna menemukan solusi dalam rancangan sistem yang sesuai. Dengan berbagai informasi dan ilmu yang diperoleh dari studi pustaka ini, penelitian yang dilakukan dapat memiliki sumber yang kuat dalam menjawab permasalahan yang ada selama ini.

\section{Metode Evaluasi}

Peneliti melakukan evaluasi untuk mengetahui apakah pengembangan aplikasi memenuhi tujuan atau tidak.
1) System Usability Scale (SUS), adalah salah satu metode uji sistem yang ditujukan bagi pengguna sistem. Tujuan dari SUS adalah untuk melakukan pengukuran kegunaan dan manfaat dari suatu sistem dengan cara yang cepat dan mudah namun tetap dapat diandalkan [11]. Uji ini dikategorikan murah, sebab bentuk uji ini hanya sebuah kuis singkat yang tidak memerlukan banyak sumber daya untuk mengelola, sehingga dapat meminimalisasi biaya.

2) Blackbox testing, adalah metode pengujian perangkat lunak dimana struktur/desain internal sistem tidak diketahui oleh penguji [10]. Prosedur tersebut didasarkan pada analisis spesifikasi, fungsional dan nonfungsional dari suatu komponen sistem dengan tidak melihat struktur kode dan informasi internal sistem. Semua pengujian yang dilakukan didasarkan pada sudut pandang pengguna, yaitu apa yang harus diselesaikan oleh perangkat lunak diperhatikan. Pada tes ini, peneliti hanya berfokus dan menguji input dan output dari sistem saja. Input dan output tersebut dinyatakan dengan valid atau tidak valid dan sesuai atau tidak sesuai. Tujuan utama dari black box testing adalah untuk memeriksa apakah perangkat lunak bekerja sesuai persyaratan atau sesuai kebutuhan pengguna atau tidak.

\section{HASIL DAN PEMBAHASAN}

Dari hasil wawancara dan observasi, permasalahan yang didapatkan disajikan pada Gbr.1. Berdasarkan fishbone diagram, dapat diketahui permasalahan-permasalahan yang ada pada sistem berjalan sebagai berikut:

- PS-STIS belum memiliki sistem yang menangani manajemen pengetahuan dikalangan pegawai, sehingga beberapa proses seperti penyimpanan, penyebaran, dan pengambilan pengetahuan masih dilakukan secara terpisah

- Rotasi dan mutasi pegawai di PS-STIS tergolong cepat, sehingga pengetahuan dan pengalaman terkait pekerjaan yang dimiliki pegawai lama belum dapat sepenuhnya diwariskan

- Frekuensi pelatihan pegawai baru terhadap bidang pekerjaan barunya masih kurang, sehingga kerap kali pegawai baru mengalami masalah terkait pekerjaan

- Pekerjaan yang ada di PS-STIS tergolong banyak dan kompleks, sehingga benar-benar dibutuhkan pengetahuan dan pengalaman yang kuat dalam menyelesaikan pekerjaan yang ada

- Dokumentasi terhadap pengetahuan dan file pekerjaan yang belum terukur dan terintegrasi. Dalam hal ini, penyimpanan berbagai pengetahuan masih dilakukan secara terpisah oleh masing-masing pegawai, bahkan terdapat beberapa pengetahuan yang belum terdokumentasi dan masih berada pada ingatan pegawai.

- Dokumentasi pengetahuan dan file penting sering terselip atau bahkan hilang, sebab belum terdapat media penyimpanan yang jelas.

- Adanya pembatasan hak akses antar pegawai menyebabkan perbedaan pengetahuan yang dimiliki. Hal tersebut menyebabkan terpusatnya informasi dan pengetahuan pada pihak atau jabatan tertentu, sehingga apabila pejabat tersebut pindah maka informasi yang dimilikinya akan ikut terbawa.

- Faktor manusia yang memiliki sifat lupa, terkadang menyebabkan hilangnya pengetahuan yang bersifat tacit 
- Belum terdapat SOP (Standard Operating Procedure) yang jelas terkait alur penyimpanan, penyebaran, dan pencarian informasi terkait pekerjaan. Hal tersebut menyebabkan masing-masing pegawai melakukan interpretasi dan menggunakan cara masing-masing untuk memanajemen pengetahuan.

- Alur komunikasi bertanya antar pegawai tidak beraturan, tidak terdokumentasi secara jelas dan seringnya muncul duplikasi pertanyaan membuat sistem tanya jawab belum efektif. Hal tersebut sering terjadi karena setelah melakukan pertanyaan, penanya tidak melakukan dokumentasi secara baik (hanya menggunakan jawaban untuk diri sendiri dan tidak berfikir dokumentasi setelah dia pindah dari unit tersebut)

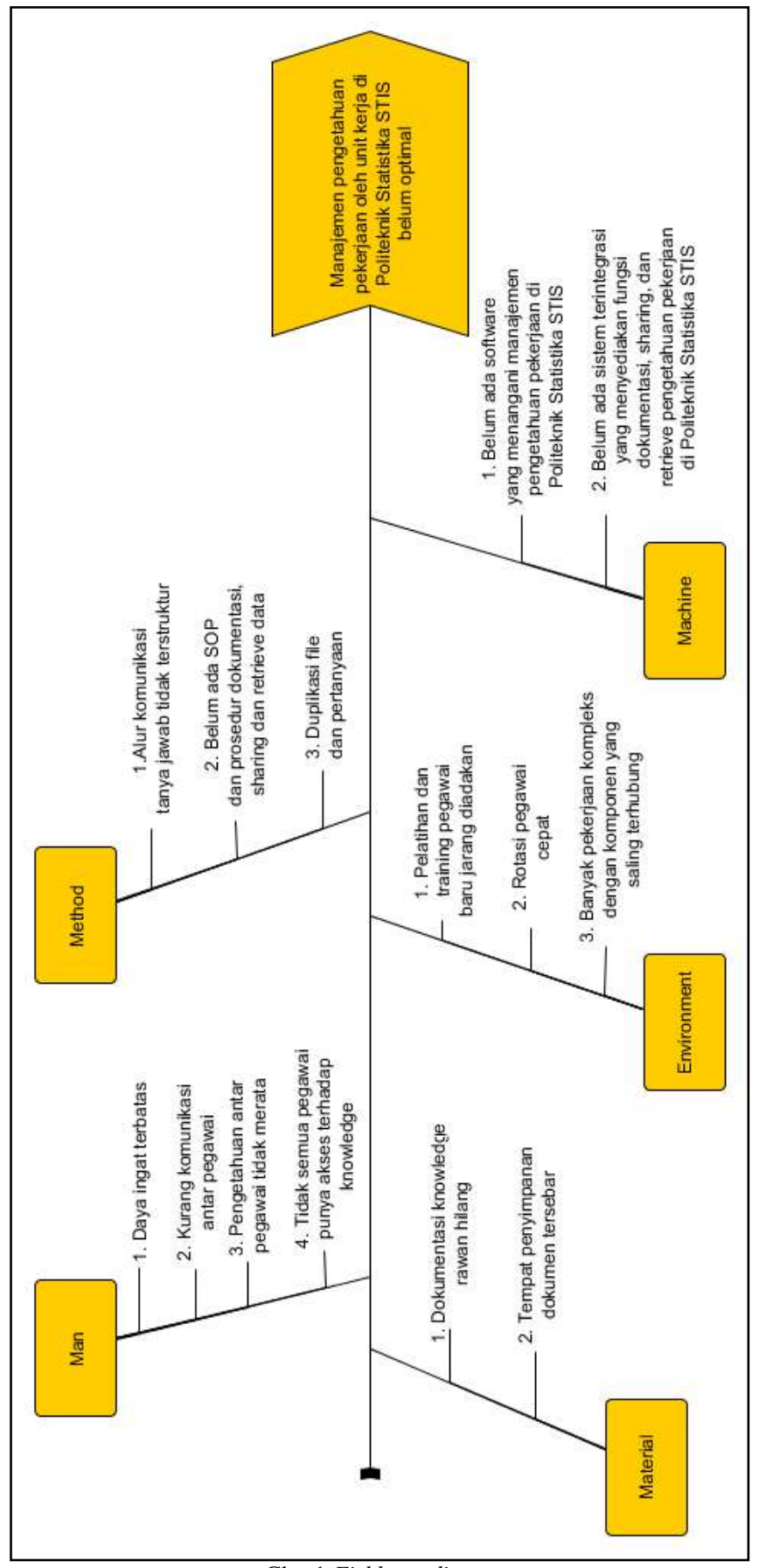

Gbr. 1 Fishbone diagram

\section{A. Rancangan Aplikasi}

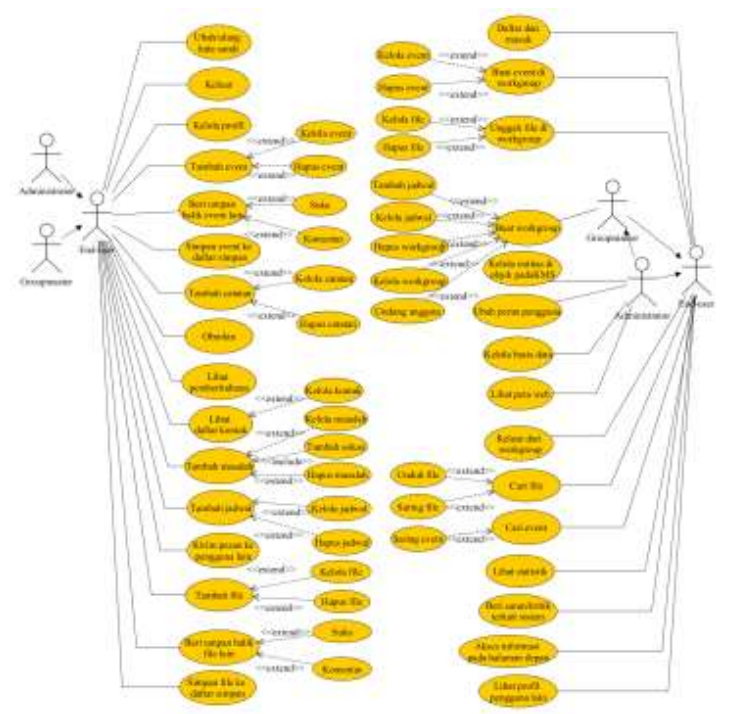

Gbr. 2 use case diagram

Usecase yang digunakan dapat dilihat pada Gbr.2. Aktivitas pengguna pada sistem yang dibangun mengikuti proses bisnis usulan, yang melibatkan 3 aktor utama, yaitu pengguna biasa, groupmaster, dan administrator. Ketiga level pengguna tersebut memiliki aktivitas sesuai dengan hak akses masing-masing. Sedangkan bisnis proses sistem usuan digambarkan pada gambar 3.

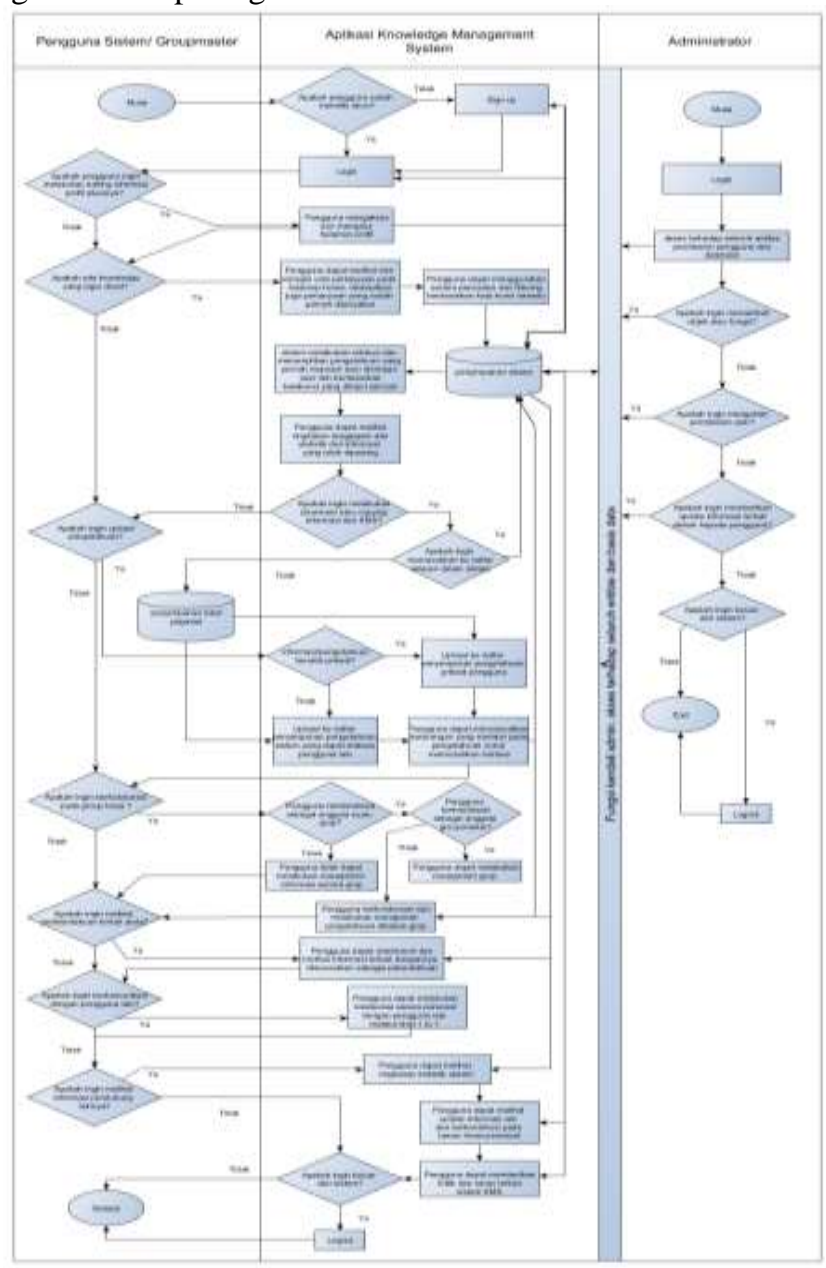

Gbr. 3 Bisnis proses sistem usulan 


\section{B. Arsitektur}

Arsitektur sistem yang dibangun berbasis web, dan bersifat online. Bahasa pemrograman yang digunakan pada backend adalah Python, dengan framework web Django. Basis data pada sistem yang dibuat menggunakan MySQL dan aplikasi phpMyAdmin sebagai pengolah basis data Arsitektur sistem digambarkan pada Gbr 4.

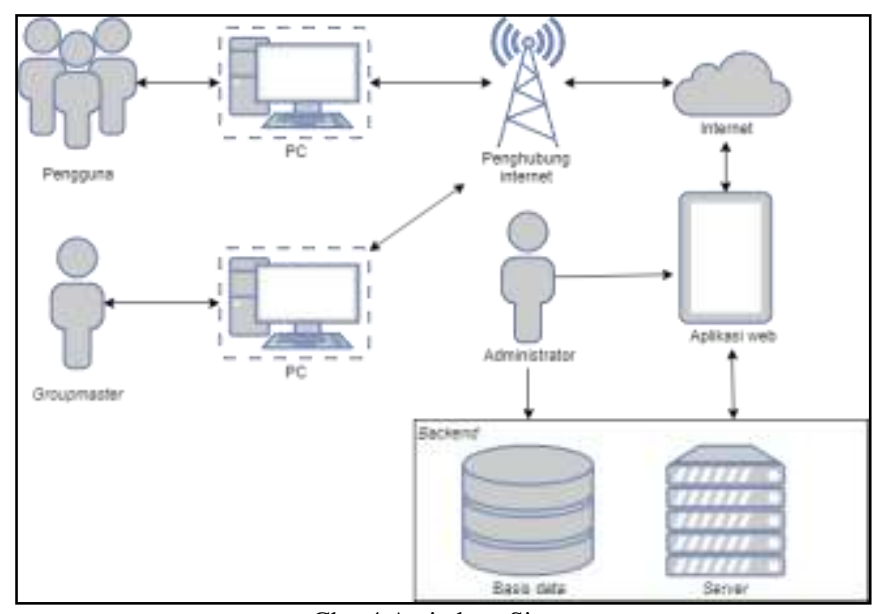

Gbr. 4 Arsitektur Sistem

\section{Implementasi}

Pada Gbr.5 sampai dengan Gbr. 10 menunjukkan implementasi sistem yang telah dibuat.

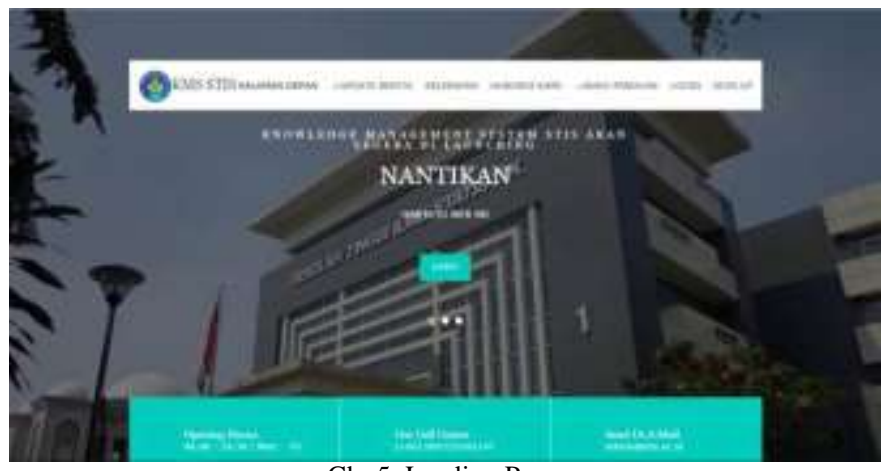

Gbr 5. Landing Page

Antarmuka pada sistem web yang dibangun dibagi menjadi dua bagian yaitu halaman index yang dapat dilihat oleh semua pengunjung, baik yang terdaftar atau tidak, dan halaman home ataupun isi dari sistem web, yang hanya dapat diakses oleh pengguna terdaftar. Sedangkan pada sisi pengguna terdaftar, terdapat perbedaan hak akses antara pengguna biasa, groupmaster, dan administrator. Perbedaan yang mendasari hal ini adalah hak akses tiap-tiap pengguna. Selain hal diatas, terdapat satu laman khusus bagi administrator tempat dimana manajemen seluruh entitas dan basis data dilakukan.

Pada sistem web yang didesain, terdapat beberapa fitur yang disediakan untuk melakukan manajemen pengetahuan, seperti Register dan Login sebagai autentikasi pengguna terdaftar, Home sebagai halaman awal pengguna yang masuk, Profil sebagai halaman dokumentasi identitas pengguna, Blog sebagai tempat manajemen pengetahuan milik pribadi, Post yang bertujuan untuk kolaborasi penyimpanan antar pengguna, Workgroup sebagai media kolaborasi pengguna yang tergabung dalam satu unit kerja. Selain itu juga terdapat menu Contact yang digunakan oleh pengguna untuk berkomunikasi secara personal dengan individu lain, dan menu Extra sebagai menu tambahan dan pendukung dalam menjalankan sistem web Knowledge Management.

\begin{tabular}{|c|c|}
\hline Menu & Post $x$ \\
\hline Home & $\begin{array}{l}\text { Workgroup } \gg \\
\text { Dashboard }\end{array}$ \\
\hline Search & Supervisar Dashtioard \\
\hline $\begin{array}{l}\text { Profil } \% \\
\text { My Profil }\end{array}$ & Contact $»$ \\
\hline Edit Profil & Message \\
\hline Edrt Password & Extra $*$ \\
\hline$B \log \varnothing$ & Notification \\
\hline My Event & Statistics \\
\hline My pile & Kritk/Saran \\
\hline Event Saved: & Extra Information \\
\hline Fie'saved & Situmap \\
\hline My Schedule & \\
\hline My Problem: & Panduan \\
\hline My Note: & Menggunakan \\
\hline Post » & Aplikasi \\
\hline Event Summary & $\begin{array}{l}\text { Berikut dilampirkan link untuk } \\
\text { menuju ke halaman user }\end{array}$ \\
\hline All File: & manual \\
\hline File Summary & Continue Reading ? \\
\hline
\end{tabular}

Gbr. 6 Menu dan Sub Menu

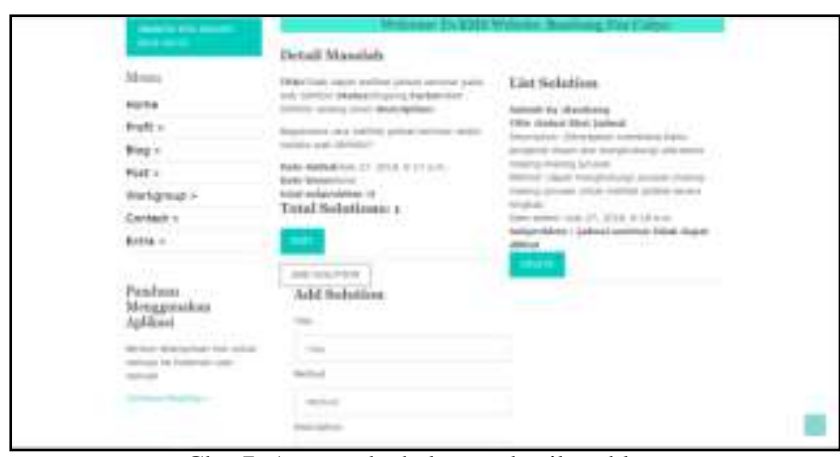

Gbr. 7 Antarmuka halaman detail problem

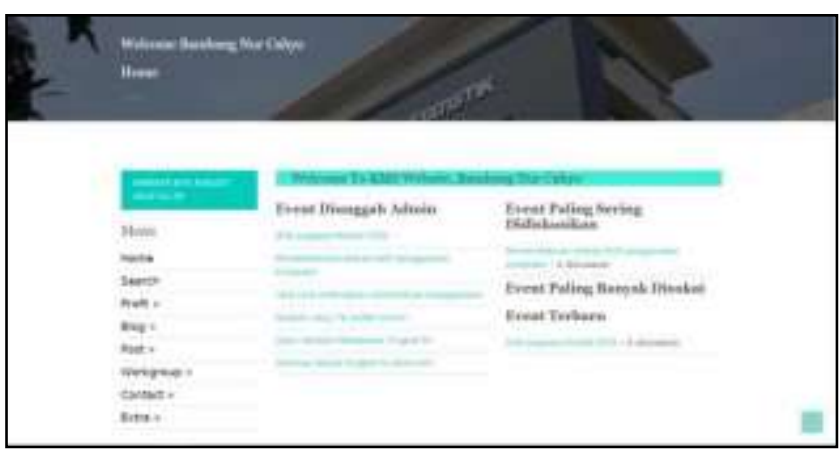

Gbr. 8 Halaman home 

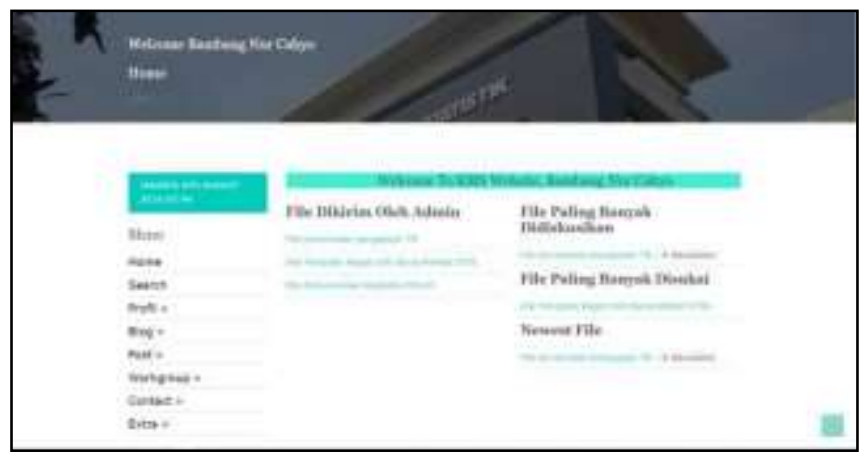

Gbr. 9 Halaman file management

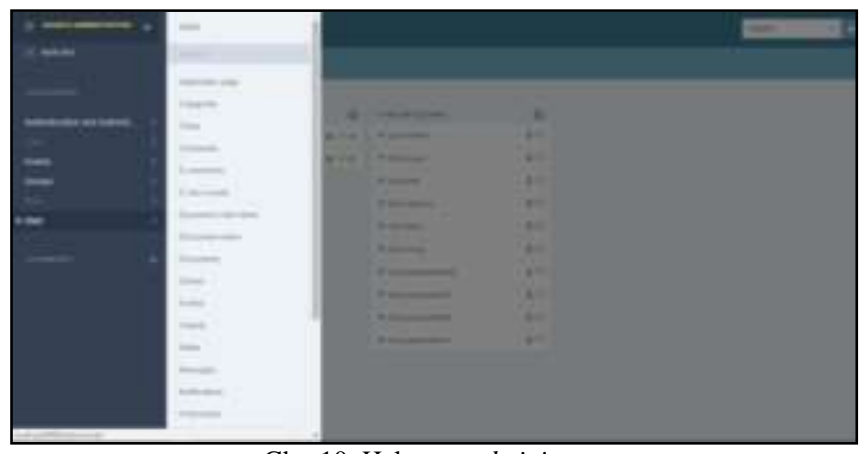

Gbr. 10 Halaman administrator

Hak akses yang dimiliki oleh pengguna biasa adalah mengakses seluruh fungsi manajemen informasi, terkecuali fungsi kelola workgroup yang dimiliki oleh groupmaster dan kelola seluruh entitas yang dimiliki oleh administrator. Fungsi yang dapat dijalan seperti contoh membuat event, menyimpan file, melakukan kolaborasi dalam bentuk obrolan dua arah dengan pengguna lain, bergabung bersama workgroup dan melakukan kolaborasi didalamnya. Hak akses dalam hal pengelolaan workgroup dimiliki oleh groupmaster. Beberapa diantaranya seperti undang pengguna untuk masuk kedalam workgroup, ubah informasi tentang workgroup, hingga melakukan pengeditan dan penghapusan daftar pengetahuan yang ada didalam workgroup yang menjadi tanggungjawabnya.

Administrator

Hak akses yang dimiliki administrator adalah yang paling banyak dibandingkan pengguna lain. Administrator dapat melakukan pengubahan pada entitas dan objek yang ada didalam sistem web, mengubah hak akses pengguna yang ada, melakukan pengaturan basis data, hingga melakukan penambahan dan penghapusan objek yang tersimpan. Hak akses terakhir dimiliki oleh pengguna biasa. Seluruh akses manajemen pengetahuan, baik secara individu, grup yang didalamnya ia terdaftar, maupun semua pengetahuan yang diunggah untuk umum dapat diakses. Namun, akses tersebut memiliki pembatasan, berupa hanya bisa melakukan sunting dan hapus pengetahuan yang diunggahnya saja.

\section{Evaluasi}

\section{1) Black Box Testing}

Berikut disajikan tabel hasil pengujian blackbox yang telah dilakukan oleh peneliti:
TABEL I

HASIL PENGUJIAN BLACKBOX

\begin{tabular}{|c|c|c|c|}
\hline $\begin{array}{l}\text { Test } \\
\text { Case } \\
\text { ID }\end{array}$ & Input & Output & $\begin{array}{c}\text { Hasil } \\
\text { Penguj } \\
\text { ian }\end{array}$ \\
\hline TC01 & $\begin{array}{l}\text { Pengguna membuka } \\
\text { alamat web aplikasi } \\
\text { KMS }\end{array}$ & $\begin{array}{l}\text { Sistem mengarahkan pada Landing } \\
\text { page }\end{array}$ & Sesuai \\
\hline TC02 & $\begin{array}{l}\text { Pengguna melakukan } \\
\text { login }\end{array}$ & $\begin{array}{l}\text { Apabila kombinasi username dan } \\
\text { password benar, sistem akan } \\
\text { mengarahkan ke halaman home, } \\
\text { apabila salah maka akan muncul } \\
\text { peringatan }\end{array}$ & Sesuai \\
\hline TC03 & $\begin{array}{l}\text { Pengguna melakukan } \\
\text { pendaftaran akun }\end{array}$ & $\begin{array}{l}\text { Apabila masukan yang diberikan } \\
\text { sesuai dengan arahan aplikasi, } \\
\text { maka pendaftaran akan sukses, } \\
\text { apabila tidak sesuai maka akan } \\
\text { muncul peringatan }\end{array}$ & Sesuai \\
\hline TC04 & $\begin{array}{l}\text { Pengguna } \\
\text { menggunakan fitur lupa } \\
\text { password dengan } \\
\text { memasukkan email }\end{array}$ & $\begin{array}{l}\text { Sistem akan mengirimkan link } \\
\text { reset password ke email yang } \\
\text { dimasukkan pengguna, apabila di } \\
\text { klik akan diarahkan ke form } \\
\text { pengisian password baru }\end{array}$ & Sesuai \\
\hline TC05 & $\begin{array}{l}\text { Pengguna menekan } \\
\text { menu home }\end{array}$ & $\begin{array}{l}\text { Sistem akan mengarahkan ke } \\
\text { halaman home, pengguna dapat } \\
\text { memasukkan nama knowledge } \\
\text { yang belum ada pada sistem }\end{array}$ & Sesuai \\
\hline TC06 & $\begin{array}{l}\text { Pengguna menekan } \\
\text { submenu my profil } \\
\text { pada menu profil }\end{array}$ & $\begin{array}{l}\text { Sistem akan mengarahkan ke } \\
\text { halaman profil pengguna }\end{array}$ & Sesuai \\
\hline TC07 & $\begin{array}{lr}\text { Pengguna } & \text { memasukkan } \\
\text { nama knowledge } & \text { kn di } \\
\text { kedalam form r dan } \\
\text { halaman home dan } \\
\text { menekan submit }\end{array}$ & $\begin{array}{l}\text { Sistem akan menyimpan nama } \\
\text { knowledge yang dimasukkan dan } \\
\text { menampilkannya di halaman home }\end{array}$ & Sesuai \\
\hline TC08 & $\begin{array}{l}\text { Pengguna menekan } \\
\text { submenu edit profil } \\
\text { pada menu profil }\end{array}$ & $\begin{array}{l}\text { Sistem akan mengarahkan } \\
\text { halaman edit profil pengguna }\end{array}$ & Sesuai \\
\hline TC09 & $\begin{array}{l}\text { Pengguna menekan } \\
\text { submenu edit password } \\
\text { pada menu profil }\end{array}$ & $\begin{array}{l}\text { Sistem akan mengarahkan ke } \\
\text { halaman edit password pengguna }\end{array}$ & Sesuai \\
\hline TC10 & $\begin{array}{lr}\text { Pengguna menekan } \\
\text { submenu my event } \\
\text { pada menu blog }\end{array}$ & $\begin{array}{l}\text { Sistem akan mengarahkan ke } \\
\text { halaman event yang dimiliki oleh } \\
\text { pengguna }\end{array}$ & Sesuai \\
\hline TC11 & $\begin{array}{l}\text { Pengguna menekan } \\
\text { submenu my file pada } \\
\text { menu blog }\end{array}$ & $\begin{array}{l}\text { Sistem akan mengarahkan ke } \\
\text { halaman file yang dimiliki oleh } \\
\text { pengguna }\end{array}$ & Sesuai \\
\hline TC12 & $\begin{array}{l}\text { Pengguna menekan } \\
\text { submenu my schedule } \\
\text { pada menu blog }\end{array}$ & $\begin{array}{l}\text { Sistem akan mengarahkan ke } \\
\text { halaman jadwal yang dimiliki oleh } \\
\text { pengguna }\end{array}$ & Sesuai \\
\hline TC13 & $\begin{array}{l}\text { Pengguna menekan } \\
\text { submenu my problem } \\
\text { pada menu blog }\end{array}$ & $\begin{array}{l}\text { Sistem akan mengarahkan ke } \\
\text { halaman problem yang dimiliki } \\
\text { oleh pengguna }\end{array}$ & Sesuai \\
\hline TC14 & $\begin{array}{l}\text { Pengguna menekan } \\
\text { submenu my note pada } \\
\text { menu blog }\end{array}$ & $\begin{array}{l}\text { Sistem akan mengarahkan ke } \\
\text { halaman catatan yang dimiliki oleh } \\
\text { pengguna }\end{array}$ & Sesuai \\
\hline TC15 & $\begin{array}{ll}\text { Pengguna } & \text { menekan } \\
\text { menu search } & \end{array}$ & $\begin{array}{l}\text { Sistem akan mengarahkan ke } \\
\text { halaman pencarian seluruh } \\
\text { knowledge yang disimpan pada } \\
\text { penyimpanan umum }\end{array}$ & Sesuai \\
\hline TC16 & $\begin{array}{l}\text { Pengguna menekan } \\
\text { submenu all event pada } \\
\text { menu post }\end{array}$ & $\begin{array}{l}\text { Sistem akan mengarahkan ke } \\
\text { halaman daftar semua event yang } \\
\text { disimpan pada penyimpanan } \\
\text { umum sistem }\end{array}$ & Sesuai \\
\hline TC17 & $\begin{array}{l}\text { Pengguna menekan } \\
\text { tombol add event yang } \\
\text { berada pada keterangan } \\
\text { event tersebut }\end{array}$ & $\begin{array}{llr}\text { Sistem akan } & \text { otomatis } \\
\text { menambahkan event } & \text { tersebut } \\
\text { kedalam daftar simpan event } \\
\text { pengguna }\end{array}$ & Sesuai \\
\hline TC18 & $\begin{array}{l}\text { Pengguna menekan } \\
\text { tombol filter event } \\
\text { yang terdiri dari by } \\
\text { category, by status, dan } \\
\text { by priority }\end{array}$ & $\begin{array}{l}\text { Sistem akan mengarahkan ke } \\
\text { halaman yang bersesuaian, yaittu } \\
\text { halaman event berdasarkan } \\
\text { category atau event berdasarkan } \\
\text { status atau bahkan event } \\
\text { berdasarkan priority }\end{array}$ & Sesuai \\
\hline TC19 & $\begin{array}{l}\text { Pengguna menekan } \\
\text { pada salah satu judul } \\
\text { event yang ada pada } \\
\text { halaman daftar event }\end{array}$ & $\begin{array}{l}\text { Sistem akan mengarahkan ke } \\
\text { halaman detail dari event tersebut }\end{array}$ & Sesuai \\
\hline TC20 & $\begin{array}{l}\text { Pengguna menekan } \\
\text { tombol like pada event } \\
\text { yang sedang dilihat }\end{array}$ & $\begin{array}{l}\text { Sistem akan otomatis menambah } \\
\text { jumlah like pada event tersebut } \\
\text { dan menampilkannya }\end{array}$ & Sesuai \\
\hline TC21 & $\begin{array}{l}\text { Pengguna memasukkan } \\
\text { komentar kedalam } \\
\text { form komentar dan } \\
\text { menekan add comment }\end{array}$ & $\begin{array}{lr}\text { Sistem akan otomatis menyimpan } \\
\text { komentar tersebut } & \text { dan } \\
\text { menampilkannya pada halaman } \\
\text { detail event tersebut. }\end{array}$ & Sesuai \\
\hline TC22 & Pengguna & Sistem akan mengarahkan ke & Sesuai \\
\hline
\end{tabular}




\begin{tabular}{|c|c|c|c|}
\hline & $\begin{array}{lll}\text { submenu } & \text { event } \\
\text { summary pada } & \text { menu } \\
\text { post } & & \\
\end{array}$ & $\begin{array}{l}\text { halaman ringkasan } \\
\begin{array}{l}\text { event yang } \\
\text { disimpan pada } \\
\text { umum sistem }\end{array}\end{array}$ & \\
\hline TC23 & $\begin{array}{l}\text { Pengguna menekan } \\
\text { submenu all file pada } \\
\text { menu post }\end{array}$ & $\begin{array}{l}\text { Sistem akan mengarahkan ke } \\
\text { halaman daftar semua file yang } \\
\text { disimpan pada penyimpanan } \\
\text { umum sistem }\end{array}$ & Sesuai \\
\hline TC24 & $\begin{array}{l}\text { Pengguna menekan } \\
\text { tombol add file yang } \\
\text { berada pada keterangan } \\
\text { file tersebut }\end{array}$ & $\begin{array}{llrr}\text { Sistem akan } & \text { otomatis } \\
\text { menambahkan } & \text { file } & \text { tersebut } \\
\text { kedalam daftar } & \text { simpan } & \text { file } \\
\text { pengguna } & & & \end{array}$ & Sesuai \\
\hline TC25 & $\begin{array}{l}\text { Pengguna menekan } \\
\text { tombol filter file yang } \\
\text { terdiri dari by category, } \\
\text { by status, dan by } \\
\text { priority }\end{array}$ & $\begin{array}{l}\text { Sistem akan mengarahkan ke } \\
\text { halaman yang bersesuaian, yaittu } \\
\text { halaman file berdasarkan category } \\
\text { atau event berdasarkan status atau } \\
\text { bahkan event berdasarkan priority }\end{array}$ & Sesuai \\
\hline TC26 & $\begin{array}{l}\text { Pengguna menekan } \\
\text { pada salah satu judul } \\
\text { file yang ada pada } \\
\text { halaman daftar file }\end{array}$ & $\begin{array}{l}\text { Sistem akan mengarahkan ke } \\
\text { halaman detail dari file tersebut }\end{array}$ & Sesuai \\
\hline TC27 & $\begin{array}{l}\text { Pengguna menekan } \\
\text { tombol like pada file } \\
\text { yang sedang dilihat }\end{array}$ & $\begin{array}{l}\text { Sistem akan otomatis menambah } \\
\text { jumlah like pada file tersebut dan } \\
\text { menampilkannya }\end{array}$ & Sesuai \\
\hline TC28 & $\begin{array}{l}\text { Pengguna memasukkan } \\
\text { komentar kedalam } \\
\text { form komentar dan } \\
\text { menekan add comment }\end{array}$ & $\begin{array}{l}\text { Sistem akan otomatis menyimpan } \\
\text { komentar tersebut } \text { dan } \\
\text { menampilkannya pada halaman } \\
\text { detail file tersebut. }\end{array}$ & Sesuai \\
\hline TC29 & $\begin{array}{l}\text { Pengguna menekan } \\
\text { submenu file summary } \\
\text { pada menu post }\end{array}$ & $\begin{array}{l}\text { Sistem akan mengarahkan ke } \\
\text { halaman ringkasan file yang } \\
\text { disimpan pada penyimpanan } \\
\text { umum sistem }\end{array}$ & Sesuai \\
\hline TC30 & $\begin{array}{lr}\begin{array}{l}\text { Pengguna } \\
\text { submenuekan } \\
\text { dashboard } \\
\text { pada menu workgroup }\end{array} \\
\end{array}$ & $\begin{array}{l}\text { Sistem akan mengarahkan ke } \\
\text { halaman daftar workgroup yang } \\
\text { dimiliki oleh pengguna tersebut }\end{array}$ & Sesuai \\
\hline TC31 & $\begin{array}{l}\text { Pengguna menekan } \\
\text { tombol setting }\end{array}$ & $\begin{array}{l}\text { Apabila terdapat undangan } \\
\text { kedalam workgroup oleh } \\
\text { groupmaster, akan dimunculkan } \\
\text { tanda lonceng }\end{array}$ & Sesuai \\
\hline TC32 & $\begin{array}{l}\text { Groupmaster mengisi } \\
\text { form undang dengan } \\
\text { username pengguna } \\
\text { dan menekan invite }\end{array}$ & $\begin{array}{l}\text { Sistem akan otomatis mengirim } \\
\text { undangan untuk masuk ke } \\
\text { workgroup kepada pengguna } \\
\text { tersebut melalui aplikasi KMS dan } \\
\text { email }\end{array}$ & Sesuai \\
\hline TC33 & $\begin{array}{lr}\text { Pengguna menekan } \\
\text { salah satu nama } \\
\text { workgroup yang ada } \\
\text { pada daftar workgroup } \\
\text { miliknya }\end{array}$ & $\begin{array}{l}\text { Sistem akan mengarahkan ke } \\
\text { halaman detail informasi } \\
\text { workgroup tersebut }\end{array}$ & Sesuai \\
\hline TC34 & $\begin{array}{l}\text { Pengguna menekan } \\
\text { tombol daftar event } \\
\text { pada workgroup }\end{array}$ & 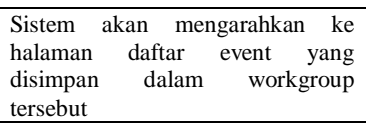 & Sesuai \\
\hline TC35 & $\begin{array}{l}\text { Pengguna menekan } \\
\text { tombol buat event pada } \\
\text { workgroup }\end{array}$ & $\begin{array}{l}\text { Sistem akan mengarahkan ke } \\
\text { halaman form pembuatan event } \\
\text { pada workgroup tersebut }\end{array}$ & Sesuai \\
\hline TC36 & $\begin{array}{l}\text { Pengguna menekan } \\
\text { tombol daftar file pada } \\
\text { workgroup }\end{array}$ & $\begin{array}{l}\text { Sistem akan mengarahkan ke } \\
\text { halaman daftar file yang disimpan } \\
\text { dalam workgroup tersebut }\end{array}$ & Sesuai \\
\hline TC37 & $\begin{array}{l}\text { Pengguna menekan } \\
\text { tombol buat file pada } \\
\text { workgroup }\end{array}$ & $\begin{array}{l}\text { Sistem akan mengarahkan ke } \\
\text { halaman form pembuatan file pada } \\
\text { workgroup tersebut }\end{array}$ & Sesuai \\
\hline TC38 & $\begin{array}{l}\text { Pengguna menekan } \\
\text { tombol daftar jadwal } \\
\text { pada workgroup }\end{array}$ & $\begin{array}{l}\text { Sistem akan mengarahkan ke } \\
\text { halaman daftar jadwal yang dibuat } \\
\text { oleh groupmaster dalam } \\
\text { workgroup tersebut }\end{array}$ & Sesuai \\
\hline TC39 & \begin{tabular}{ll}
\multicolumn{2}{c}{ Groupmaster menekan } \\
tombol edit pada \\
halaman detail infor \\
workgroup
\end{tabular} & $\begin{array}{l}\text { Sistem akan mengarahkan ke } \\
\text { halaman edit detail informasi } \\
\text { workgroup tersebut }\end{array}$ & Sesuai \\
\hline TC40 & $\begin{array}{lr}\text { Supervisor } & \text { menekan } \\
\text { submenu } & \text { supervisor } \\
\text { dashboard pada menu } \\
\text { workgroup }\end{array}$ & $\begin{array}{l}\text { Sistem akan mengarahkan ke } \\
\text { halaman daftar seluruh workgroup } \\
\text { yang ada pada sistem. }\end{array}$ & Sesuai \\
\hline TC41 & $\begin{array}{l}\text { Pengguna menekan } \\
\text { submenu user pada } \\
\text { menu contact }\end{array}$ & $\begin{array}{l}\text { Sistem akan mengarahkan ke } \\
\text { halaman daftar seluruh pengguna } \\
\text { terdaftar pada sistem. }\end{array}$ & Sesuai \\
\hline TC42 & $\begin{array}{lr}\text { Pengguna menekan } \\
\text { salah satu nama } \\
\text { pengguna lain }\end{array}$ & $\begin{array}{l}\text { Sistem akan mengarahkan ke } \\
\text { halaman profil dari pengguna yang } \\
\text { dituju }\end{array}$ & Sesuai \\
\hline TC43 & $\begin{array}{l}\text { Pengguna menekan } \\
\text { submenu message pada } \\
\text { menu contact }\end{array}$ & $\begin{array}{l}\text { Sistem akan mengarahkan ke } \\
\text { halaman kotak masuk direct } \\
\text { message dari pengguna lain }\end{array}$ & Sesuai \\
\hline TC44 & $\begin{array}{l}\text { Pengguna menekan } \\
\text { tombol sent pada } \\
\text { halaman inbox message }\end{array}$ & $\begin{array}{l}\text { Sistem akan mengarahkan ke } \\
\text { halaman pesan terkirim direct } \\
\text { message ke pengguna lain }\end{array}$ & Sesuai \\
\hline TC45 & Pengguna & Sistem akan mengarahkan ke & Sesuai \\
\hline
\end{tabular}

\begin{tabular}{|c|c|c|c|}
\hline & $\begin{array}{l}\text { tombol create pada } \\
\text { halaman inbox message }\end{array}$ & halaman membuat message & \\
\hline TC46 & $\begin{array}{lr}\text { Pengguna } & \text { menekan } \\
\text { submenu notification } \\
\text { pada menu extra }\end{array}$ & $\begin{array}{l}\text { Sistem akan mengarahkan ke } \\
\text { halaman daftar seluruh notifikasi } \\
\text { yang dikirimkan sistem kepada } \\
\text { pengguna tersebut. }\end{array}$ & Sesuai \\
\hline TC47 & $\begin{array}{l}\text { Pengguna menekan } \\
\text { submenu statistics pada } \\
\text { menu extra }\end{array}$ & $\begin{array}{l}\text { Sistem akan mengarahkan ke } \\
\text { halaman yang berisi beberapa } \\
\text { diagram yang menunjukkan entitas } \\
\text { yang dimiliki oleh pengguna. }\end{array}$ & Sesuai \\
\hline TC48 & $\begin{array}{l}\text { Pada halaman statistics, } \\
\text { pengguna menekan } \\
\text { tombol see all }\end{array}$ & $\begin{array}{l}\text { Sistem akan mengarahkan ke } \\
\text { halaman yang berisi beberapa } \\
\text { diagram yang menunjukkan entitas } \\
\text { dalam sistem secara keseluruhan. }\end{array}$ & Sesuai \\
\hline TC49 & $\begin{array}{l}\text { Pengguna menekan } \\
\text { submenu critics pada } \\
\text { menu extra }\end{array}$ & $\begin{array}{l}\text { Sistem akan mengarahkan ke } \\
\text { halaman yang berisi form } \\
\text { kritik/saran }\end{array}$ & Sesuai \\
\hline TC50 & $\begin{array}{l}\text { Pengguna mengetikkan } \\
\text { kritik/saran pada form } \\
\text { dan menekan submit }\end{array}$ & $\begin{array}{l}\text { Sistem akan menyimpan } \\
\text { kritik/saran kedalam basis data dan } \\
\text { dapat dilihat oleh administrator }\end{array}$ & Sesual \\
\hline TC51 & $\begin{array}{lr}\text { Pengguna } & \text { menekan } \\
\text { submenu } & \text { extra } \\
\text { information pada menu } \\
\text { extra }\end{array}$ & $\begin{array}{l}\text { Sistem akan mengarahkan ke } \\
\text { halaman yang berisi beberapa } \\
\text { informasi tambahan dari } \\
\text { administrator, seperti informasi } \\
\text { yang bentuknya google form, } \\
\text { google docs, dll. }\end{array}$ & Sesuai \\
\hline TC52 & $\begin{array}{l}\text { Administrator menekan } \\
\text { submenu sitemap pada } \\
\text { menu extra }\end{array}$ & $\begin{array}{l}\text { Sistem akan mengarahkan ke } \\
\text { halaman yang berisi daftar dan } \\
\text { cabang dari peta web KMS. }\end{array}$ & Sesuai \\
\hline TC53 & $\begin{array}{l}\text { Administrator } \\
\text { mengakses halaman } \\
\text { login ke admin page } \\
\text { dan memasukkan } \\
\text { kombinasi username } \\
\text { dan password yang } \\
\text { sesuai }\end{array}$ & $\begin{array}{l}\text { Sistem akan mengarahkan ke } \\
\text { halaman } \\
\text { Administrator tersebut dapat } \\
\text { melakukan pengelolaan penuh atas } \\
\text { entitas yang ada pada aplikasi } \\
\text { KMS }\end{array}$ & Sesuai \\
\hline
\end{tabular}

\section{2) SUS}

Bentuk dari evaluasi ini adalah dengan memberikan kuesioner SUS kepada 5 orang pegawai yang berasal dari beberapa unit kerja di PS-STIS. Pemilihan responden didasarkan bahwa pengguna akhir dari aplikasi KMS nantinya adalah pegawai PS-STIS. Tabel 2 menampilkan jawaban dari responden yang telah mengisi kuesioner SUS.

TABEL II

HASIL SUS

\begin{tabular}{|l|l|l|l|l|l|l|l|l|l|l|l|l|}
\hline \multirow{2}{*}{ Responden } & \multicolumn{10}{|c|}{ Jumlah } & $\begin{array}{l}\text { Nilai } \\
\text { SUS }\end{array}$ \\
\cline { 2 - 14 } & $\mathbf{1}$ & $\mathbf{2}$ & $\mathbf{3}$ & $\mathbf{4}$ & $\mathbf{5}$ & $\mathbf{6}$ & $\mathbf{7}$ & $\mathbf{8}$ & $\mathbf{9}$ & $\mathbf{1 0}$ & & \\
\hline 1 & 2 & 3 & 3 & 0 & 3 & 3 & 2 & 3 & 2 & 0 & 21 & 52,5 \\
\hline 2 & 3 & 3 & 3 & 3 & 3 & 4 & 4 & 3 & 3 & 3 & 32 & 80 \\
\hline 3 & 3 & 3 & 4 & 3 & 3 & 2 & 3 & 3 & 3 & 3 & 30 & 75 \\
\hline 4 & 4 & 3 & 4 & 4 & 4 & 2 & 4 & 3 & 3 & 3 & 34 & 85 \\
\hline 5 & 3 & 3 & 4 & 3 & 3 & 3 & 3 & 3 & 2 & 4 & 31 & 77,5 \\
\hline \multicolumn{11}{|c|}{} & \multicolumn{11}{|c|}{ Rata-rata nilai SUS } \\
\hline
\end{tabular}

Berdasarkan hasil evaluasi aplikasi menggunakan kuesioner SUS, didapatkan hasil rata-rata nilai SUS sebesar 74. Hasil SUS tersebut berada diatas batas minimal penerimaan nilai SUS yaitu sebesar 68. Dapat disimpulkan bahwa aplikasi usulan dapat diterima (acceptable) oleh pengguna aplikasi, dalam hal ini adalah pegawai Polstat STIS.

\section{KESIMPULAN}

Berdasarkan pada penelitian yang telah dilakukan, diperoleh beberapa kesimpulan. Aplikasi purwarupa knowledge management system yang dibangun memiliki beberapa fitur terintegrasi yang mendukung manajemen pengetahuan pegawai, seperti penyimpanan, pendistribusian, kolaborasi, dan pengambilan pengetahuan. Aplikasi purwarupa knowledge management system dapat membantu pemangku kepentingan dalam mengumpulkan dan 
mendokumentasikan pengetahuan yang dimiliki di dalam satu aplikasi, sehingga tidak tercecer atau hilang.

Aplikasi purwarupa knowledge management system memiliki fitur penyimpanan, kolaborasi, distribusi dan pengambilan pengetahuan, yang dapat dijadikan salah satu sumber dan acuan bagi pegawai untuk menyelesaikan permasalahan yang dihadapi. Aplikasi prototipe knowledge management system dapat menyimpan pengetahuan setiap pengguna yang terdaftar, meskipun yang bersangkutan sudah dipindahkan atau mutasi, sehingga record tersimpan dapat dijadikan informasi pendukung bagi pegawai. Aplikasi prototipe knowledge management system yang telah dibangun telah melalui uji blackbox dan SUS dengan hasil yang sesuai dengan harapan.

\section{DAFTAR PUSTAKA}

[1] H.M. Jogiyanto, Analisis dan Disain Sistem Informasi, Yogyakarta: Andi, 1999.

[2] Girard, John P., Girard, JoAnn L., "Defining knowledge management Toward an applied compendium" Online Journal of Applied Knowledge Management. 3 (1): 14. 2015
[3] Probst, G., Raub, S. \& Romhardt. K., "Managing Knowledge: Building Blocks for Success". 2000

[4] Nonaka, I. Management of Knowledge Creation. Tokyo: Nihon Keizai Shinbun-sha. 1990

[5] K. Dalkir, Knowledge Management in Theory and Practice, Burlington USA: Elsevier Butterworth-Heinemann, 2015

[6] P. A. Setianingtyas, Pembangunan Knowledge Management System Kendala dan Solusi Kegiatan Pencacahan Badan Pusat Statistik. Skripsi Politeknik Statistika STIS, 2017

[7] S.W. Kurnia, T. K. Ditha, Penerapan Kowledge Management System (KMS) Studi Kasus Bagian Teknisi dan Jaringan Fakultas Ilmu Komputer Universitas Sriwijaya, https://ejournal.unsri.ac.id/index.php/jsi/index, 2014

[8] S. Munish, K. Kuljit, "A Review of Open Source Software Development Life Cycle Models", International Journal of Software Engineering and its Applications, India 2014.

[9] Ilyas Nuryasin. "Prototype of Personal Knowledge Management on Higher Education". Jurnal Informatika:Jurnal Pengembangan IT (JPIT), Vol.03, No.01, Januari 2018.

[10] J. Gao, H.S. J. Tsao, Ye Wu. "Testing and Quality Assurance for Component-based Software", Artech House. pp. 170-. ISBN 978-158053-735-3, 2003

[11] J. Brooke,. "SUS: a "quick and dirty" usability scale". In P. W. Jordan, B. Thomas, B. A. Weerdmeester, \& A. L. McClelland. Usability Evaluation in Industry, London: Taylor and Francis, 1996. 